\title{
Peraturan dan Pengendalian: Menjelaskan Penurunan Produksi Pangan di Jawa 1940-1946 dan Kelaparan 1944-1945*
}

\section{PIERRE VAN DER ENG}

Australian National University

Email: pierre.vandereng@anu.edu.au

\begin{abstract}
The paper discusses the major reasons for the drop in food production in Java during the period of Japanese occupation. Statistics on the acreage and production of six main foodstuff during the year 1940-1946 showed significant reduction of food production in Java after 1942. This reduction is explained as the result of several physical limitation to the production and marketing process of foodstuff. The article explicate several other factors that added to the principal reason for the fall in food production after 1942. The principal reason is laid on the control system of the Javanese rice economy that had reduced the real purchasing price of grain. This resulted in little incentive for peasants to pursue surplus production outside of their household subsistence needs. The only incentive was a negative incentive of forced deliveries.
\end{abstract}

\begin{abstract}
Abstrak
Makalah ini menguraikan penjelasan utama mengenai penurunan produksi pangan di Jawa selama pendudukan Jepang. Data statistik tentang area tanam dan produksi panen enam tanaman pangan utama selama tahun 1940-6 menunjukkan bahwa produksi pangan di Jawa mengalami penurunan yang signifikan setelah tahun 1942. Penurunan ini telah dijelaskan sebagai hasil dari beberapa hambatan fisik dalam proses produksi dan pemasaran produk makanan. Makalah ini mengemukakan bahwa faktor-faktor lain menambah alasan utama mengapa produksi turun dengan sangat cepat setelah tahun 1942. Alasan utamanya adalah sistem pengendalian ekonomi beras Jawa menurunkan harga pembelian riil padi. Ini memberi sedikit insentif positif bagi petani untuk melanjutkan produksi surplus di luar kebutuhan subsisten rumah tangga mereka. Satu-satunya insentif adalah yang negatif adalah pengiriman paksa.
\end{abstract}

Keywords: famine; food production; Japanese occupation; Java

Kata kunci: kelaparan; Jawa; produksi pangan; pendudukan Jepang

*) Terjemahan ke Bahasa Indonesia dari: Van der Eng, Pierre, 'Regulation and Control: Explaining the Decline of Food Production in Java, 1940-46' in Kratoska, Paul H. (ed.) Food Supplies and the Japanese Occupation in Southeast Asia. (London: Macmillan, 1998) 187-207. Penulis berterima kasih kepada Shigeru Sato dan Paul Kratoska atas komentar mereka pada versi sebelumnya dari makalah ini dan kepada Akemi Inoue atas terjemahan bijaksana dari publikasi yang relevan dalam bahasa Jepang. 


\section{Pengantar}

Pendudukan Jepang di Jawa menyebabkan sebuah pergolakan besar, namun tingkat keseluruhan dari gejolak ekonomi sulit untuk dinilai karena tidak adanya indikator aktivitas ekonomi yang ringkas di seluruh Jawa selama tahun-tahun yang tidak menyenangkan ini. Pada tahun 1930an pemerintah kolonial di Indonesia menggunakan produksi pangan sebagai indikator utama untuk memantau perkembangan ekonomi di Jawa, dengan alasan bahwa kebanyakan orang di Jawa bekerja di sektor pertanian (Maandcijfers over den Economischen Toestand der Inheemsche Bevolking op Java en Madoera) ${ }^{1}$, dan karena data produksi yang luas memang ada untuk enam jenis tanaman pangan utama di Jawa untuk masing-masing tahun 1940-6, angka-angka ini setidaknya dapat memberi gambaran keseluruhan kecenderungan dalam aktivitas ekonomi (Geoogste Uitgestrektheden en Productie van de Voornaamste Voedingsgewassen op Java en Madoera 1937-1946, 1947).

Bagian pertama makalah ini menjelaskan tentang penilaian keandalan data selama masa perang dalam produksi pangan sebagai tolak ukur penurunan pasokan pangan. Bagian kedua menjelaskan mengenai beberapa perbedaan utama antara sistem yang digunakan pemerintah kolonial Belanda untuk mengatur pasar beras domestik di Indonesia dan pengaturan untuk pembelian serta distribusi yang diterapkan oleh pemerintah Jepang di Jawa. Bagian ketiga mengemukakan argumen bahwa penurunan pasokan pangan di Jawa selama pendudukan Jepang tidak disebabkan oleh regulasi ekonomi beras, namun oleh pilihan sistem peraturan yang sebagian besar bertujuan untuk menggantikan mekanisme pemasaran yang ada.

\section{Pelaporan Tentang Produksi Makanan}

Sebelum pendudukan Jepang, Kantor Pusat Statistik (Centraal Kantoor voor de Statistiek) memantau tanaman pangan tahunan utama di Jawa (Van de Graaff, 1955: 13-22; Ecimovic, 1957) dengan menggunakan laporan bulanan tentang area tanam, hasil panen dan lahan yang gagal dari semua tanaman pertanian tahunan. Data dikumpulkan oleh kepala desa (lurah) atau juru tulis (carik) dari lebih 20.000 desa di Jawa, dan diserahkan ke asisten wedana di 2.100 kecamatan. Setiap asisten wedana menggabungkan data dan meneruskannya ke wedana di sekitar 420 kabupaten, dan wedana tersebut kemudian melaporkan informasi tersebut ke Kantor Pusat Statistik di Jakarta dan ke kantor utama Dinas Penyuluhan Pertanian (Landbouwvoorlichtingsdienst) di karesidenan mereka. Pekerja lapangan untuk Dinas Penyuluhan Pertanian menggunakan perkiraan visual dan pemeriksaan secara acak untuk melihat bahwa pelaporan desa tetap akurat, dan perkiraan penggunaan lahan harus sesuai dengan data survei kadaster desa, yang direvisi setiap sepuluh tahun sekali.

1) Selama tahun 1930 an, Departemen Urusan Ekonomi menerbitkan laporan bulanan mengenai situasi ekonomi penduduk asli Jawa, yang berisi banyak indikator. 
Untuk menghitung hasil rata-rata, Kantor Pusat Statistik menggunakan contoh panen. Dalam kasus padi, angka tersebut berasal dari Dinas Pajak Tanah (Landrentedienst) di Departemen Keuangan, yang menilai produktivitas sawah untuk mengetahui pajak pertambahan tanah. Contoh panen tersebut diambil dari sekitar 20.000 bidang tanah dari 1.500-2.000 meter persegi, dan sampelnya bervariasi setiap sepuluh tahun ketika revisi pajak tanah terjadi. Kepala desa mengatur dan mengelola sistem tersebut, dan menerima 8 persen dari hasil pajak tanah sebagai imbalan untuk memelihara pencatatan penggunaan lahan.

Dinas Penyuluhan Pertanian membawa contoh panen untuk tanaman non-padi, namun staf lapangan yang dimiliki terlalu sedikit untuk mengatur sistem contoh panen yang sebanding dengan Dinas Pajak Tanah. Selama tahun 1920 dan 1930an, peningkatan jumlah produksi non-beras tahunan diperkirakan berdasarkan contoh tersebut (De Arbeid van het Centraal Kantoor voor de Statistiek, in het Bijzonder met Betrekking tot de Welvaart der Inheemsche Bevolking; Mededeelingen der Regeering omtrent Enkele Onderwerpen van Algemeen Belang, 1928: 103-9; Economische Weekblad van NederlandschIndie, 1940: 1820-1). Pada tahun 1939 sekitar 58 persen dari jumlah produksi pangan non-beras diperkirakan melalui potongan masing-masing 100 meter persegi, yang mana petugas Dinas Penyuluh Pertanian memilih secara acak setiap tahunnya. Meskipun bidang tanah sampel tersebut berjumlah sekitar 6.600 pada tahun 1939, mereka tidak mencakup semua tanaman di seluruh kecamatan. Perkiraan tersebut dilakukan berdasarkan contoh panen pada tahun-tahun sebelumnya atau di kecamatan tetangga yang digunakan untuk melengkapi data hasil panen untuk semua kecamatan.

Kantor Pusat Statistik menggabungkan perkiraan area tanam yang diterima dari asisten wedana, perkiraan hasil padi rata-rata dari Dinas Pajak Tanah, dan perkiraan rata-rata hasil lahan pertanian non-beras dari Dinas Penyuluhan Pertanian untuk menghitung total produksi pangan tanaman dari seluruh Jawa (Scheltema, 1930: 285-300; Scheltema, 1930/31: 296340). Hasil tebukti dapat dipercaya, dan pejabat dari Kantor Pusat Statistik dan Dinas Penyuluhan Dinas Pertanian menganggap pengaturan ini sangat memuaskan untuk keperluan pemantauan persediaan makanan. ${ }^{2}$ Perkiraan tersebut mengindikasikan bahwa rata-rata persediaan makanan di Jawa pada umumnya cukup memadai, dan lokasi spesifik yang diidentifikasi sebagai daerah yang bermasalah diperiksa secara lebih rinci, khususnya oleh Lembaga Penelitian Gizi (Instituut voor Volksvoeding) di 1930an (Posthumus dan van Veen, 1949: 229-36, 261-8, 316-23; van Veen, 1950: 374-83).

Otoritas kolonial di Indonesia sangat menghargai pelaporan statistik yang akurat tentang produksi makanan karena ada keseimbangan antara

2) Pada tahun 1930an sistem ini diperluas ke Bali, Lombok, Sumbawa dan Sulawesi Selatan. 
pasokan makanan dan populasi di Jawa. Setelah 1900, permintaan makanan yang terus meningkat sebagian besar dipenuhi oleh produksi tanaman pangan non-beras di daerah dataran tinggi yang baru dibuka, tetapi batasbatas perluasan lahan mulai terlihat pada akhir 1920-an, dan pemerintah kolonial mulai memperkenalkan langkah-langkah untuk memfasilitasi dengan lebih intensif penggunaan lahan pertanian yang ada (Voedingsproblemen en overheidspolitiek op Jawa en Madoera, 1940: 663-72; Hadiwinoto, 1959: 761-3). Sebagai contoh, investasi publik dalam perbaikan pekerjaan irigasi untuk mencapai distribusi air yang lebih efisien selama musim kemarau memungkinkan hasil panen yang meningkat sebanyak dua hingga tiga kali lipat. Sejak akhir 1920-an, pemerintah juga menetapkan sistem untuk penggandaan dan distribusi varietas unggul beras dan tanaman pangan lainnya. Namun, efektivitas dari langkah-langkah tersebut tidak dapat diambil begitu saja, dan pengawasan ketat terhadap produksi makanan dianggap penting untuk menghindari kekurangan gizi atau kelaparan.

Latar belakang ini menunjukkan bahwa sistem pelaporan statistik pada produksi tanaman pangan utama di Jawa sangat komprehensif ketika orang Jepang tiba. Sistem ini tampaknya terus berfungsi sepanjang pendudukan Jepang. Ada ketidaksinambungan di tingkat administrasi atas karena pemerintah kolonial pusat runtuh dan pemerintah Jepang menghapuskan pemerintah provinsi, tetapi tingkat administrasi yang lebih rendah, yang diawaki oleh layanan sipil pribumi (pangreh praja), sebagian besar masih tetap ada. Selain itu, pihak otoritas Jepang kemudian mengembangkan rencana untuk meningkatkan produksi pangan di Jawa dengan memperluas Layanan Penyuluhan Pertanian (Noomuka, dilanjutkan setelah Agustus 1945 sebagai Djawatan Pertanian Rakjat), dan memperbaruinya sejalan dengan prinsipprinsip Jepang dalam melakukan pekerjaan penyuluhan (Landbouwvoorlichting in Oost-Jawa tijdens de Japansche Bezetting, 1946: 174-90).

Data produksi pangan selama 1940-6 ditemukan pada akhir 1947 di Kantor Penelitian Umum (Chosashitsu, setelah Agustus 1945, Kantor Penjelidikan Oemoem), yang telah memasukkan Kantor Pusat Statistik dan ditempatkan di gedung sebelumnya(Het Centraal Kantoor voor de Statistiek, 1946: 12; Fukami, 1985: 48-49; Fukami, 1988: 21-36). Praktik pengumpulan data di tingkat kabupaten sebelum perang dipertahankan hingga pertengahan tahun 1945, tetapi setelah Jepang menyerah, data dikumpulkan oleh Dinas Penyuluhan Pertanian di tingkat residensi, kadang-kadang berdasarkan estimasi visual area panen di tingkat administrasi yang lebih rendah dan perkiraan kasar per residensi hasil panen rata-rata. Ada kemungkinan bahwa perkiraan ini melebihi luas panen; karena kemunduran dan penghentian pendaftaran desa tentang penggunaan lahan, prosedur serupa digunakan selama tahun 1950an, dan survei sampel yang dilakukan pada tahun 1955 menunjukkan bahwa perkiraan visual seperti itu sekitar 14 persen terlalu 
tinggi dari yang seharusnya (Ecimovic, 1957; Hollinger dan Tan, 1957: 5-7).

Tabel 1 menunjukkan area panen sawah irigasi yang dilaporkan pada tahun 1940-6 bersamaan dengan seperangkat perkiraan yang disiapkan oleh Komando Asia Tenggara berdasarkan survei foto udara 8,5 persen dari lahan irigasi di Jawa pada bulan Mei 1946 (Fotografische Opname van de Rijstproduceerende Gebieden op Java en Madoera, 1946: 236), dan angka yang dikumpulkan pada tahun 1950, tahun pasca-perang pertama di mana data lengkap tersedia lagi. Untuk tahun 1946 angka yang dihasilkan oleh survei

Tabel 1. Luas panen padi sawah di Jawa, 1941-46 dan 1950 (x 1,000 ha)

\begin{tabular}{|c|c|c|c|c|c|c|c|c|}
\hline Karesidenan & 1941 & 1942 & 1943 & 1944 & 1945 & 1946 & Survei 1946 & 1950 \\
\hline Banten & 106 & 107 & 111 & 97 & 65 & 90 & 111 & 98 \\
\hline Jakarta & 383 & 370 & 387 & 313 & 272 & 340 & 311 & 360 \\
\hline Bogor & 200 & 208 & 206 & 188 & 161 & 169 & 184 & 173 \\
\hline Priangan & 320 & 329 & 334 & 276 & 247 & 266 & 226 & 315 \\
\hline Cirebon & 269 & 270 & 278 & 252 & 246 & 225 & 196 & 264 \\
\hline Jawa Barat & 1,278 & 1,285 & 1,315 & 1,126 & 989 & 1,090 & 1,028 & 1,210 \\
\hline Pekalongan & 215 & 222 & 224 & 196 & 152 & 177 & 153 & 214 \\
\hline Semarang & 206 & 198 & 207 & 178 & 175 & 170 & 144 & 185 \\
\hline Pati & 191 & 183 & 185 & 140 & 150 & 150 & 147 & 143 \\
\hline Banyumas & 210 & 213 & 208 & 150 & 114 & 126 & 101 & 159 \\
\hline Kedu & 218 & 225 & 221 & 176 & 163 & 138 & 148 & 179 \\
\hline Yogyakarta & 77 & 80 & 82 & 74 & 62 & 62 & 162 & 74 \\
\hline Surakarta & 200 & 202 & 201 & 181 & 149 & 158 & 54 & 196 \\
\hline Jawa Tenggah & 1,317 & 1,324 & 1,328 & 1,096 & 965 & 979 & 909 & 1,150 \\
\hline Madiun & 175 & 179 & 175 & 158 & 134 & 159 & 130 & 164 \\
\hline Bojonegoro & 202 & 149 & 173 & 170 & 109 & 127 & 109 & 143 \\
\hline Surabaya & 180 & 169 & 190 & 179 & 165 & 146 & 128 & 164 \\
\hline Kediri & 148 & 149 & 155 & 140 & 123 & 129 & 129 & 119 \\
\hline Malang & 180 & 180 & 179 & 149 & 129 & 140 & 107 & 156 \\
\hline Besuki & 202 & 193 & 208 & 222 & 214 & 197 & 165 & 192 \\
\hline Madura & 62 & 60 & 66 & 70 & 48 & 50 & 36 & 54 \\
\hline Jawa Timur & 1,148 & 1,079 & 1,145 & 1,088 & 922 & 947 & 803 & 992 \\
\hline Jumlah Jawa & 3,743 & 3,687 & 3,789 & 3,310 & 2,877 & 3,016 & 2,740 & 3,352 \\
\hline
\end{tabular}

Sumber: Untuk 1941-6 Geoogste Uitgestrektheden en Productie van de Voornaamste Voedingsgewassen op Java en Madoera 1937-1946 (Jakarta: Centraal Kantoor voor de Statistiek, 1947); untuk survei 1946 'Photographic Survey of the Rice Producing Areas of Java and Madura', (14 June 1946), British Public Record Office, FO371/53889 (F9802); untuk 1950 Panen dan Penanaman Tanaman Bahan Makanan Rakjat jang Terutama di Djawa dan Madura (1950). 
fotografi adalah 9 persen lebih rendah daripada data resmi. Mengingat bahwa sekitar 15 persen padi dipanen di luar musim utama bulan April-September (de Vries, 1933: 2109-12), dan sekitar 6 persen dari total area yang ditanam dengan padi gagal setiap tahun selama tahun 1930an, data resmi untuk tahun 1946 kemungkinan sangat rendah, dan dufaan ini dikonfirmasi oleh data yang ada pada tahun 1950. Total area pada tahun 1950 adalah 11 persen lebih tinggi dari pada tahun 1946, namun banyak karesidenan menunjukkan sedikit peningkatan dibanding tahun 1946. Oleh karenaitu, dua perbandingan tersebut menunjukkan bahwa angka yang dikumpulkan selama tahun 1940an cukup akurat. Mengingat bahwa sistem pelaporannya transparan dan relatif mudah untuk diperiksa, sulit untuk mengasumsikan bahwa area yang dipanen sangat kurang dilaporkan.

Selama tahun 1920an dan 1930an ada kekhawatiran tentang kemungkinan bahwa kepala desa salah mengartikan hasil panen padi. Namun, perbandingan contoh panen Dinas Pajak dan Layanan Penyuluhan Pertanian pada akhir tahun 1930an menunjukkan bahwa kesalahan tersebut rata-rata cenderung terjadi. Bila kepala desa memiliki lebih dari 8 persen lahan desa, mereka cenderung melaporkan hasil panen dari contoh panen, karena dengan demikian mereka menghemat pembayaran pajak tanah mereka sendiri. Bila kepala memiliki kurang dari 8 persen lahan desa, mereka cenderung melaporkannya lebih banyak, karena ini akan meningkatkan keuntungan mereka dari 8 persen dari pendapatan pajak tanah yang mereka kumpulkan di desa-desa. ${ }^{3}$ Jadi, kepentingan kepala desa mungkin merupakan faktor penting dalam melaporkan hasil panen rata-rata. Skema pembelian beras yang diterapkan oleh pemerintah Jepang setelah tahun 1943 memberi beberapa alasan untuk melaporkan produksi pangan di desa mereka, apakah untuk melindungi persediaan makanan lokal dari permintaan beras, mendapatkan beras untuk operasi pasar gelap, atau hanya karena peningkatan beban kerja administratif mereka.

Statistik yang tersedia menunjukkan bahwa hasil rata-rata dari semua tanaman pangan menurun secara signifikan selama pendudukan Jepang, seperti yang ditunjukkan pada Tabel 2. Alasan penurunan ini termasuk memburuknya operasi dan pemeliharaan pekerjaan irigasi, tidak adanya upaya terpadu dari petugas Dinas Penyuluhan Pertanian untuk memerangi penyakit tanaman dan hama-hama (terutama tikus-tikus), dan kegagalan panen yang meluas pada tahun 1944 karena kekeringan. Namun, rata-rata yang dilaporkan pada tahun 1945 dan 1946 berada di bawah rata-rata minimum yang tercatat selama tahun 1923-41, dan fakta ini menunjukkan bahwa terjadi kekurangan pelaporan. Secara khusus, para pengamat mencatat bahwa pada tahun 1946 tanaman padi di lapangan tampak baik, yang mungkin mengindikasikan

3) Investigasi yang tidak dipublikasikan oleh J. van der Ploeg pada akhir 1930an. Komunikasi pribadi dilakukan oleh Prof. E. de Vries kepada penulis, April 1988. 
Tabel 2. Hasil rata-rata enam tanaman pangan utama, 1930an dan 1940-6 (ton per hektar)

\begin{tabular}{ccccccccc}
\hline & $1930 a n$ & 1940 & 1941 & 1942 & 1943 & 1944 & 1945 & 1946 \\
\hline Padi sawah & 2.13 & 2.28 & 2.26 & 2.13 & 2.02 & 2.00 & 1.91 & 1.71 \\
Padi lading & 1.22 & 1.35 & 1.47 & 1.29 & 1.31 & 0.99 & 0.70 & 0.70 \\
Jagung & 0.97 & 0.96 & 1.09 & 0.98 & 0.88 & 0.84 & 0.65 & 0.63 \\
Ubi kayu & 8.27 & 8.08 & 8.71 & 8.95 & 7.92 & 6.35 & 5.88 & 5.62 \\
Ubi jalar & 6.65 & 6.73 & 7.18 & 6.95 & 6.01 & 5.73 & 4.33 & 4.37 \\
Kacang tanah & 0.75 & 0.78 & 0.81 & 0.82 & 0.72 & 0.62 & 0.56 & 0.56 \\
Kedelai & 0.69 & 0.70 & 0.77 & 0.73 & 0.71 & 0.58 & 0.50 & 0.52 \\
\hline
\end{tabular}

Catatan: Kolom untuk tahun 1930an didasarkan pada rata-rata tahunan untuk 1930-9. Hasil padi diberikan dalam bentuk padi tangkapan, hasil singkong dan ubi jalar dalam hal umbi segar.

Sumber: Untuk tahun 1930an, Indisch Verslag (1932-40); untuk tahun 1940-6, Geoogste Uitgestrektheden en Productie van de Voornaamste Voedingsgewassen op Java en Madoera 1937-1946 (Jakarta: Centraal Kantoor voor de Statistiek, 1947).

bahwa hasil panen rata-rata yang sangat rendah yang dilaporkan untuk tahun tersebut tidak dapat diterima (BPRO, inv.nr.: F0371/53889 (F9802); FO371/53907(F12706)).

Sehubungan dengan pengumpulan angka yang menunjukkan hasil panen tanaman pangan non-padi, Dinas Penyuluhan Pertanian menderita kekurangan tenaga kerja setelah penahanan staf Belanda. Pejabat Indonesia mengambil alih tugas tersebut, namun saat itu keterbatasan moda transportasi menuju kantor manjadi kendala bagi mereka. Terlebih lagi, mulai pertengahan tahun 1944 para pekerja lapangan dari layanan dinas tersebut dimobilisasi oleh orang Jepang untuk melaksanakan tugas-tugas yang berhubungan upaya untuk meningkatkan produksi padi di Jawa (Sato, 1994: 176-7; Van Der Eng, 1994: 17-21; Kurasawa, 1998: 35-61). Tugas-tugas ini membuat mereka memiliki sedikit waktu untuk mengerjakan contoh panen karena mereka tetap sibuk menyampaikan arahan metode penanaman padi kepada petani. Hasil rata-rata pada tahun 1944 dan 1945 mungkin hanya diperkirakan atas dasar pengalaman masa lalu. Ada juga indikasi bahwa petani menyabotase contoh panen dengan menipiskan tanaman pada malam hari sebelum panen (Soebardjo, 1994: 7).

Hasil rata-rata semua tanaman pangan turun terus menerus selama pendudukan Jepang, sebuah tren yang dapat dilihat pada Tabel 2. Mengingat bahwa Republik Indonesia melanjutkan sistem pengadaan beras Jepang setelah Jepang menyerah pada Agustus 1945, hasil panen tahun 1946 mungkin Juga kurang dilaporkan (Van der Eng, 1994: 42-51). Namun, hasil pada tahun 1944 juga terkena dampak kekeringan. Dengan asumsi bahwa hasil panen yang dilaporkan terlalu rendah pada tahun 1945 dan 1946, Gambar 1 memberikan perkiraan perkiraan angka produksi untuk tahun-tahun tersebut dengan menggunakan hasil panen rata-rata 1942/3. Untuk masing-masing 
dari tiga wilayah utama di Jawa, bagan ini menunjukkan indeks dari nilai riil produksi pangan riil yang dihitung berdasarkan harga pangan 1940, dan indeks luas panen total. Perkiraan ulang produksi pada tahun 1945 dan 1946 dengan menggunakan hasil 1942/3 meningkatkan produksi pada tahun-tahun tersebut, meskipun tetap rendah.

Figur 1 menunjukkan bahwa di Jawa Barat hasil produksi riil menurun selama tahun 1941-3, meskipun terjadi peningkatan sedikit di daerah panen. Untuk Jawa Timur, luas panen turun lebih cepat daripada produksi pangan selama tahun 1944-6, yang menunjukkan bahwa produktivitas lahan meningkat. Sebagian besar penurunan produksi pangan di Jawa Barat, Jawa Tengah dan Jawa Timur dapat dijelaskan oleh pengurangan luas panen, apakah produksi pada tahun 1945 dan 1946 telah diperbaiki atau tidak. Seperti disebutkan di atas, kecil kemungkinan bahwa pengurangan area panen merupakan fungsi dari tidak adanya pelaporan. Dengan demikian, walaupun besarnya penurunan produksi pangan dapat diperdebatkan, nampak jelas bahwa produksi pangan di Jawa terutama menurun karena petani mengolah lahan mereka dengan kurang intensif, atau membiarkan lahannya menganggur.

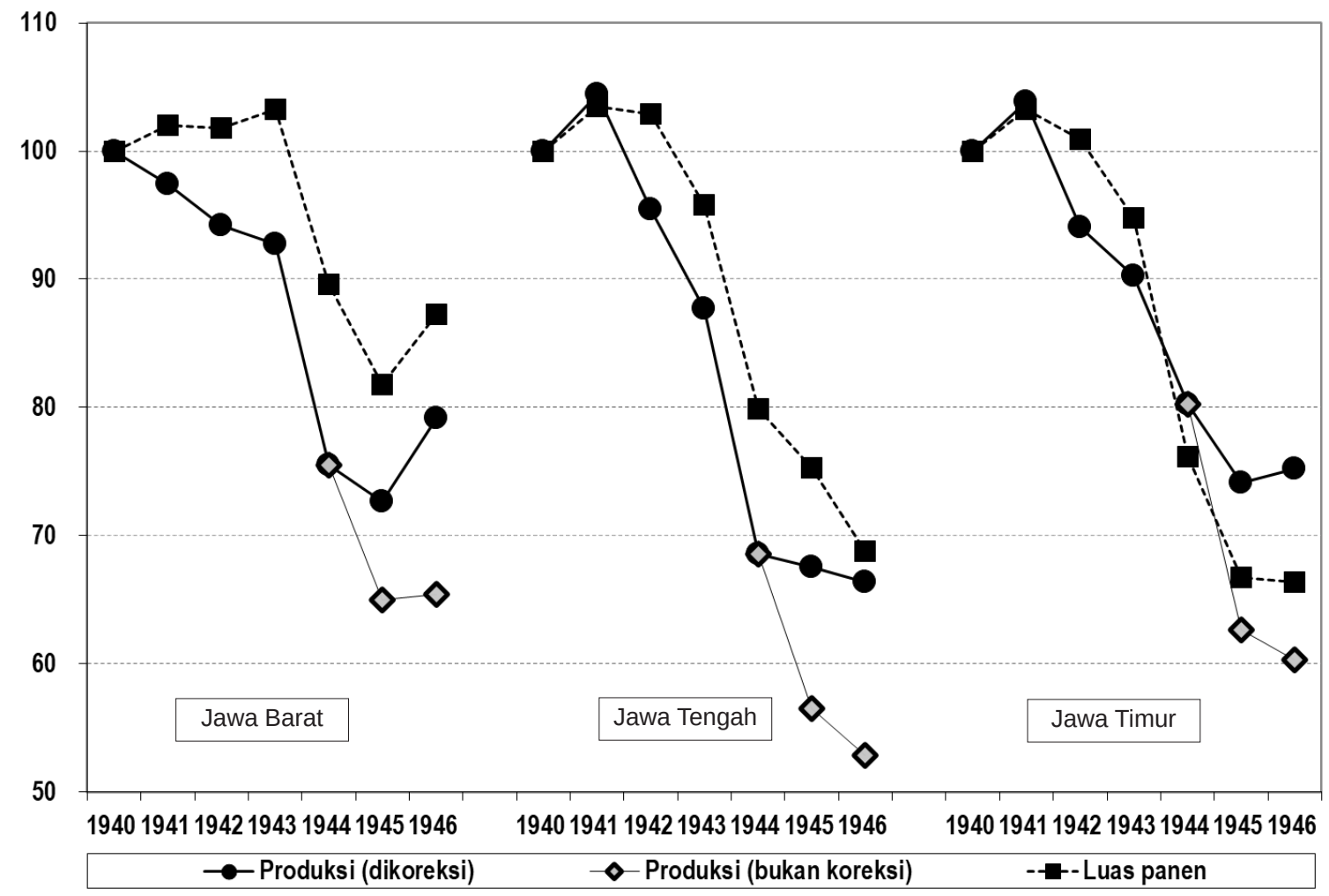

Figur 1. Indeks nilai riil produksi dan luas panen enam tanaman pangan utama, 1940-6 (1940 = 100)

Catatan: Nilai produksi riil dihitung dengan harga pedesaan tahun 1940.

Sumber: 1940 dari Indisch Verslag (1940); 1940-6 dari Geoogste Uitgestrektheden en Productie van de Voornaamste Voedingsgewassen op Java en Madoera 1937-1946 (Jakarta: Centraal Kantoor voor de Statistiek, 1947). 
Salah satu penjelasan yang mungkin untuk hasil ini adalah kegagalan panen, yang akan menunjukkan area yang ditanam lebih besar daripada area yang dipanen. Kegagalan panen mungkin meningkat karena memburuknya fasilitas irigasi yang disebabkan oleh operasi yang tidak efisien dan pemeliharaan yang buruk. Kekurangan air irigasi tentu menjadi masalah selama tahun 1944, di mana saat itu menjadi tahun yang sangat kering. Tahun terburuk sebelum pendudukan Jepang adalah 1921, ketika 453.000 ha padi irigasi (15 persen dari area yang ditanami) gagal. Namun, kegagalan panen tidak dapat menjelaskan penurunan lebih lanjut pada tahun 1945 dan stagnasi pada tahun 1946. Pada tahun 1963 dan 1964, kegagalan panen padi utama di Jawa diikuti oleh peningkatan pesat pada daerah panen dan hasil tanaman pangan lainnya, terutama jagung dan ubi jalar (Luas Panen dan Produksi Tanam2an Rakjat Berumur Pendek di Djawa dan Madura, 1963/1964). Namun, dalam kasus jagung, hasil yang dipanen menurun setelah tahun 1943 (lihat Tabel 3), yang mengindikasikan bahwa petani di Jawa tidak menanam jagung untuk mengimbangi penurunan pasokan beras selama tahun 1944/5. Daerah yang dipanen dengan ubi jalar meningkat setelah tahun 1943 sampai 350.000 ha yang belum pernah terjadi sebelumnya di tahun 1945, namun dari segi kalori, kenaikan produksi ubi jalar jauh dari cukup untuk mengimbangi jatuhnya produksi biji-bijian dan kacang-kacangan (Van Der Eng, 1994: 26$31,78-9)$.

Tabel 3. Luas panen enam tanaman pangan utama, 1940-6 dan 1950 (× 1.000 hektar)

\begin{tabular}{ccccccccc}
\hline & $\mathbf{1 9 4 0}$ & $\mathbf{1 9 4 1}$ & $\mathbf{1 9 4 2}$ & $\mathbf{1 9 4 3}$ & $\mathbf{1 9 4 4}$ & $\mathbf{1 9 4 5}$ & $\mathbf{1 9 4 6}$ & $\mathbf{1 9 5 0}$ \\
\hline Padi sawah & 3,724 & 3,743 & 3,687 & 3,789 & 3,310 & 2,877 & 3,016 & 3,352 \\
Padi lading & 365 & 357 & 338 & 343 & 262 & 241 & 244 & 223 \\
Jagung & 1,983 & 2,229 & 2,214 & 1,812 & 1,399 & 1,488 & 1,150 & 1,622 \\
Ubi kayu & 1,041 & 1,003 & 976 & 950 & 829 & 551 & 626 & 711 \\
Ubi jalar & 209 & 205 & 189 & 180 & 259 & 349 & 227 & 154 \\
Kacang tanah & 251 & 259 & 253 & 291 & 175 & 99 & 144 & 223 \\
Kedelai & 418 & 440 & 481 & 384 & 185 & 141 & 246 & 325 \\
\hline Jumlah & $\mathbf{7 , 9 9 3}$ & $\mathbf{8 , 2 3 7}$ & $\mathbf{8 , 1 3 9}$ & $\mathbf{7 , 7 4 9}$ & $\mathbf{6 , 4 1 9}$ & $\mathbf{5 , 8 3 3}$ & $\mathbf{5 , 7 2 9}$ & $\mathbf{6 , 6 1 0}$ \\
\hline
\end{tabular}

Sumber: Untuk tahun 1940-6, Geoogste Uitgestrektheden en Productie van de Voornaamste Voedingsgewassen op Java en Madoera 1937-1946 (Jakarta: Centraal Kantoor voor de Statistiek, 1947), Untuk 1950 Panen dan Penanaman Tanaman Bahan Makanan Rakjat janguhan di Djawa dan Madura (1950).

Penjelasan lain yang memungkinan terhadap penurunan penanaman padi adalah kekurangan tenaga kerja. Pada tahun 1944, Jepang merekrut sekitar 2,6 juta orang Jawa sebagai buruh dan tentara pembantu (Sato, 1994: 157). Pada awal tahun 1940-an, jumlah pekerjaan di Jawa sekitar 19 juta, dan 60 sampai 65 persen angkatan kerja terlibat dalam sektor pertanian. Namun, runtuhnya pertanian perkebunan, dan hilangnya kesempatan kerja di bidang 
industri serta sektor ekonomi non-pertanian lainnya, mendorong tenaga kerja untuk direkrut oleh orang Jepang tanpa menyebabkan kekurangan tenaga kerja yang cukup besar dan memaksa petani di seluruh pedesaan Jawa untuk meninggalkan lahan mereka dalam kondisi kosong. Ketika petani benarbenar membiarkan lahan mereka kosong, hal tersebut kemungkinan besar merupakan pilihan yang dilakukan secara sadar untuk tidak menghasilkan tanaman pangan daripada resiko yang harus diambil akibat kekurangan tenaga kerja.

Kekurangan hewan bajak menawarkan penjelasan yang agak lebih baik untuk musim gugur di daerah panen. Jumlah hewan, terutama sapi dan kerbau, turun dari 5,6 juta ekor pada tahun 1941 menjadi sekitar 4,2 juta di tahun 1945 (Kort Overzicht van de Ontwikkeling van de Economische Situatie in de Republiek Indonesia sinds Haar Oprichting, 1947: 5; ANRI, Djogya Papers, inv.nr. 5240), ${ }^{4}$ tidak hanya karena tentara Jepang membeli, tetapi juga karena banyak petani memutuskan untuk membantai ternak mereka daripada menjual hewan ke orang Jepang untuk mata uang yang terdepresiasi cepat. Penurunan total lahan panen antara tahun 1942 dan 1945 adalah 29 persen, yang sesuai dengan penurunan 25 persen pada ternak. Di sisi lain, berkurangnya kesempatan kerja di luar sektor pertanian di pedesaan Jawa mungkin telah menekan tingkat upah riil, yang sampai batas tertentu akan mendorong petani mengganti hewan dengan tenaga manusia untuk mempersiapkan ladang.

Singkatnya, hambatan fisik menghalangi petani untuk menanam beberapa lahan, namun ini tampaknya tidak menambahkan penjelasan mengenai penurunan dramatis jumlah panen tanaman pangan selama pendudukan Jepang. Mungkin, jawabannya harus dicari selanjutnya ialah memeriksa perubahan peluang untuk pemasaran tanaman pangan, dan sebagai imbalannya, para petani menjual hasil panen mereka.

\section{Peraturan Pasar Beras}

Pemerintah kolonial telah mengembangkan sistem yang cermat untuk memantau persediaan makanan di Jawa karena kekhawatirannya akan keseimbangan antara pertumbuhan populasi dan produksi pangan, namun upaya resmi untuk mempromosikan produksi pangan sebagian besar tidak dilakukan secara langsung. Pemerintah, misalnya, berinvestasi dalam pekerjaan irigasi dan penyediaan varietas padi unggul dan pupuk kimia sebagai cara untuk meningkatkan produktivitas (Van Der Eng, 1992: 10-40).

Peraturan pemerintah langsung mengenai pasar beras dimulai pada tahun 1933, ketika impor beras dibatasi karena impor beras murah dari daratan Asia Tenggara mengancam industri beras dalam negeri, sehingga membahayakan mata pencaharian sebagian besar petani padi di Jawa.

4) Dihitung berdasarkan data stok dan pemotongan data, dengan asumsi tingkat reproduksi 10 persen selama tahun 1944 dan 1945. 
Peraturan tersebut juga melindungi pasar domestik dari fluktuasi harga beras impor, yang telah menghambat pengembangan penggilingan padi, di mana industri penggilingan tumbuh dengan cepat di Indonesia setelah tahun 1933 hingga mengakibatkan kelebihan kapasitas penggilingan dan kelebihan produksi yang mengancam akan memicu penurunan harga. Pemerintah kolonial, dengan mempertimbangkan keseimbangan antara pertumbuhan penduduk dan produksi pangan, serta ancaman perang dunia baru, merasa bahwa Indonesia tidak mampu menunggu pasar beras untuk mencapai keseimbangan baru, di mana proses tersebut dinilai akan memakan waktu beberapa tahun. Dengan demikian mereka kemudian mendirikan Yayasan Bahan Makanan (Voedingsmiddelenfonds) pada bulan April 1939, meresmikan serangkaian langkah kompleks yang telah muncul sejak tahun 1933 untuk menstabilkan harga pangan di seluruh negeri dengan membeli produk makanan (terutama beras) di daerah yang mengalami surplus panen, mengatur penyimpanan dan transportasi, serta menjual produk makanan di daerah-daerah yang mengalami defisit hasil panen, terutama selama musim paceklik sebelum panen utama (Voedselproblemen en Overheidspolitiek: 67384). Dengan pecahnya Perang Dunia Kedua, tugas lembaga tersebut beralih pada pembentukan cadangan penyangga makanan untuk mengantisipasi dampak perang terhadap perdagangan internasional.

Pembentukan Yayasan Bahan Makanan pada tahun 1940 mengarah pada peraturan penggilingan padi. Lembaga tersebut kemudian membeli stok dengan harga minimum dan terjamin, di mana ia bekerja sama dengan penggilingan beras dengan hasil yang tidak dapat dijual, namun pabrik tersebut diwajibkan membeli padi dengan harga batas minimum dan ketika menjual beras tidak melebihi harga maksimum yang ditetapkan oleh lembaga tersebut. Oleh karena itu, lembaga tersebut tidak berusaha mengendalikan seluruh pasar untuk beras giling, juga tidak menangani semua beras giling atau mengatur distribusi beras giling di seluruh negeri. Dengan hanya membeli stok yang tidak dapat dijual dengan harga minimum yang dijamin, lembaga tersebut berusaha memastikan pengembalian yang adil bagi petani padi dan penggilingan padi juga sebagai upaya untuk menstabilkan harga. Sebagian besar beras terus diperdagangkan dan diangkut melalui jalur pribadi.

Secara keseluruhan, 29 persen dari hasil panen, sebesar 1,35 juta ton beras, diangkut dari daerah yang surplus ke daerah yang defisit hasil beras di Jawa pada tahun 1941 ('De Rijstpositie van Nederlandsch-Indië', 1946: 81-2). Yayasan Bahan Makanan menahan 230.000 ton pada akhir tahun 1941 dan sebagian besar biji-bijian ini digunakan sebagai stok cadangan daripada untuk operasi pasar. Selama tahun 1941, Indonesia hampir melakukan swasembada dan bahkan mampu menghasilkan surplus ekspor beras dalam jumlah kecil.

Pejabat Jepang pada awalnya tidak terlibat dalam pembelian beras, walaupun mereka meminta persediaan dari Yayasan Bahan Makanan untuk 
memberi makan pasukan Jepang dan memasok daerah perkotaan, serta beberapa intendan membeli padi dan meminta pabrik untuk memprosesnya. Tahun pertama masa pendudukan Jepang membawa hasil panen yang bagus sehingga persediaan beras berlimpah. Namun, orang Jepang mengalami kesulitan yang mengejutkan dalam usaha mereka untuk menambah persediaan beras melalui pembelian. Salah satu alasannya adalah bahwa pedagang beras enggan menerima mata uang yang baru dicetak, yang sebagian besar digunakan oleh pejabat Jepang untuk membiayai operasi mereka, di mana peredaran uang ini juga dilakukan dengan pemberian harga diskon untuk menyaingi uang penjajahan Belanda.

Pada bulan September 1942, Jepang mendirikan pengganti Yayasan Bahan Makanan, yaitu Kantor Pasokan Pangan (awalnya disebut Syokuryo Kanri Zimusho namun kemudian diganti namanya beberapa kali) (Sato, 1994: 115-53; Kurasawa, 1988: 113-80; Van der Eng, 1994: 10-17). yang pada dasarnya memerintahkan penggilingan padi untuk membeli padi selama sisa panen tahun tanam 1942/3, dan untuk menjual beras giling ke kantor makanan. Hasilnya mengecewakan, dan orang Jepang menerapkan pendekatan yang lebih sistematis untuk tahun tanam 1943/4. Semua karesidenan diberi kuota padi, dan biji-bijian tersebut harus dijual dengan harga yang terkendali ke pabrik, yang sekarang diambil alih oleh Kantor Pasokan Pangan dan dicegah beroperasi atas akun mereka sendiri. Beras giling dijual juga dengan harga yang dikontrol oleh Kantor Pasokan Pangan yang menangani distribusinya kepada militer Jepang, pasukan tambahan Indonesia, pegawai negeri sipil, kamp penahanan dan daerah perkotaan.

Pihak berwenang di karesidenan menetapkan kuota untuk kabupaten, yang pada gilirannya menetapkan kuota untuk distrik, kecamatan dan desa. Kuota ini tidak diatur secara seragam, dan pejabat tingkat bawah menandai mereka untuk memastikan bahwa beras yang terkumpul cukup memadai. Petani diwajibkan untuk menyerahkan padi secara eksklusif kepada kumiai (koperasi non-sukarela yang dimodelkan setelah nokyo Jepang). Terlepas dari organisasi yang lebih ketat ini, menjadi jelas pada bulan November 1943 bahwa kuota tidak akan terpenuhi. Mereka kemudian diturunkan dan Jepang memberikan tekanan yang lebih besar kepada petugas sipil pribumi untuk memastikan kepatuhan mereka, namun bahkan target yang dikurangi ini tidak terpenuhi (lihat Tabel 4).

Sistem yang sama digunakan untuk tahun tanam 1944/5. Namun, musim kemarau yang luar biasa memperpanjang masa tanam dan panen, dan curah hujan yang tidak mencukupi menyebabkan kerusakan luas pada tanaman padi utama. Panen yang buruk meningkatkan keengganan petani untuk menyerahkan padi ke kumiai, dan kekurangan pangan secara umum mendorong harga pasar gelap jauh di atas harga yang ditawarkan oleh Kantor Pasokan Pangan (lihat Tabel 5). Faktanya, banyak komoditas pokok 
Tabel 4. Kuota padi dan digiling oleh penggilingan padi besar, 1943-5 (x 1000 ton)

\begin{tabular}{|c|c|c|c|c|c|c|c|c|c|}
\hline & \multicolumn{3}{|c|}{1943} & \multicolumn{3}{|c|}{1944} & \multicolumn{3}{|c|}{1945} \\
\hline & Kuota & 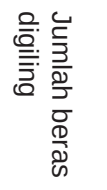 & 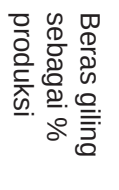 & Kuota & 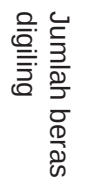 & 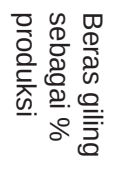 & Kuota & 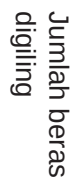 & 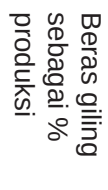 \\
\hline Jawa Barat & 656 & 640 & $22 \%$ & 792 & 396 & $17 \%$ & 509 & 220 & $10 \%$ \\
\hline Jawa Tenggah & 357 & 240 & $9 \%$ & 417 & 270 & $13 \%$ & 428 & 210 & $11 \%$ \\
\hline Jawa Timur & 626 & 611 & $23 \%$ & 877 & 679 & $18 \%$ & 795 & 558 & $25 \%$ \\
\hline Jumlah Jawa & 1,640 & 1,491 & $18 \%$ & 2,086 & 1,344 & $20 \%$ & 1,732 & 988 & $15 \%$ \\
\hline
\end{tabular}

Catatan: Kuota dan beras giling disebut tanam musim (April-Maret); 1943 kuota adalah kuota direvisi ke bawah dari aslinya dua juta ton pada bulan November 1943; 1945 digiling kerah padi untuk April-Oktober; total jumlah padi giling sebenarnya menyerah.

Sumber: Kuota dari S. Sato, War, Nationalism and Peasants. Java under the Japanese Occupation (Sydney: Allen dan Unwin, 1994): 117-123; padi giling dari Indische Collectie, Rijksinstituut voor Oorlogsdocumentatie (Amsterdam) No. 056514; produksi padi dari, Geoogste Uitgestrektheden en Productie van de Voornaamste Voedingsgewassen op Java en Madoera 1937-1946 (Jakarta: Centraal Kantoor voor de Statistiek, 1947); 1945 produksi akurat diperkirakan berdasarkan 1942-3 hasil rata-rata per residensi.

Tabel 5. Harga padi di Jawa, 1942-5 (gulden per $100 \mathrm{~kg}$ )

\begin{tabular}{ccccc}
\hline & Harga padi pasar gelap & \multicolumn{3}{c}{ Harga padi beli resmi } \\
\cline { 3 - 5 } pedesaan & padi bulu & padi cereh & gabah \\
\hline 1942 & $6.00-7.00$ & 6.43 & 6.13 & 6.17 \\
1943 & $8.00-10.00$ & 6.78 & 6.50 & 6.48 \\
1944 & $25.00-30.00$ & 7.68 & 7.36 & 7.34 \\
1945 & 200.00 & 13.39 & 13.39 & 13.28 \\
\hline
\end{tabular}

Catatan: Harga beli ditentukan harga minimum untuk tahun 1942 dan 1943, dan harga maksimum untuk 1944 dan 1945 , semua dihitung ulang dengan beras setara.

Sumber: 'De Economische Toestand van Nederlandsch-Indië tijdens de Japanse Bezetting', Statistische en Econometrische Onderzoekingen [Penelitian statistik-ekonometri], 2 (1947): 126; S. Sato, War, Nationalism and Peasants. Java under the Japanese Occupation (Sydney: Allen dan Unwin, 1994): 123.

tidak tersedia, baik karena tidak lagi diimpor (terutama tekstil) atau karena ada hambatan untuk melakukan produksi dalam negeri yang lebih besar, meningkatkan keengganan petani untuk menjual padi mereka dengan harga resmi. Banyak dari mereka yang kemudian menyembunyikan stok padinya.

Beberapa karesidenan dan kabupaten telah membatasi atau melarang ekspor beras dan padi (dan kemudian semua makanan) untuk dapat memenuhi kuota yang dibutuhkan, dan hal tersebut kemudian menjadi praktik umum. Ketika sudah jelas pada akhir tahun 1944 bahwa kuota pembelian tidak mungkin tercapai, Jepang mengumumkan larangan penjualan beras yang ditumbuk di rumah. Menjelang akhir tahun, semakin sedikitnya arus transportasi (kereta api, kapal, truk) menyebabkan orang Jepang memberlakukan swasembada pada setiap karesidenan. Langkah ini 
menurunkan surplus makanan, dan membuatnya tidak mungkin untuk mengatasi kekurangan secara drastis di beberapa daerah melalui perdagangan bebas tanaman pangan non-padi. Hal ini mungkin dapat menjelaskan mengapa daerah yang ditanami jagung dan singkong tidak meningkat pada tahun 1944 dan 1945, yaitu untuk mengkompensasi penurunan pasokan beras. Pembatasan tersebut tetap berlaku selama tahun tanam 1945/6, setidaknya sampai setelah Jepang menyerah pada Agustus 1945.

\section{Diskusi Penurunan Produksi Pangan}

Dua publikasi telah membahas penyebab penurunan produksi pangan selama pendudukan Jepang di Jawa. Aiko Kurasawa berpendapat bahwa kekurangan beras akibat penghentian perdagangan luar negeri dan 'tuntutan militer Jepang dalam skala besar' mengharuskan ditetapkannya kontrol atas ekonomi beras. Dia mengaitkan penurunan yang drastis dalam produksi pangan dengan hambatan fisik, beberapa di antaranya telah dibahas di atas, juga 'kurangnya semangat kerja' di petani di Jawa (Kurasawa, 1988: 11, 31-3, 62-8, 108). Namun, Jawa mengekspor beras pada akhir tahun 1930an, dan tidak ada Kekurangan beras pada tahun 1942 meski terdapat penangguhan perdagangan luar negeri. Persediaan makanan tetap memadai pada tahun 1943 dan persyaratan beras dari militer Jepang di Jawa tidak terlalu besar. Bahkan kuota padi yang tercantum dalam Tabel 4 seharusnya bisa dikelola. Baik sebagai jumlah absolut maupun sebagai bagian dari produksi, kuota ini lebih rendah dari volume padi yang dijual ke penggilingan padi pada tahun 1940 dan 1941.

Shigeru Sato berpendapat bahwa kekurangan beras bukan disebabkan oleh tuntutan militer Jepang, melainkan oleh sistem yang digunakan oleh pemerintah Jepang untuk mendapatkan dan mendistribusikan beras, yang pada dasarnya melumpuhkan pasokan: 'Semakin banyak orang Jepang mencoba mengendalikan pemasaran beras, semakin dia lepas kendali' (Sato, 1994: 203, 148). Dia mengatakan bahwa pihak berwenang Jepang kehilangan kendali atas situasi ini karena ketidaktahuan dan kurangnya pengalaman membuat mereka melakukan tindakan yang tidak tepat, khususnya sistem pembelian dan pasokan yang rusak dan tidak memiliki koordinasi serta penuh dengan peluang untuk dikorupsi. Selain itu, hambatan dari para pangreh praja juga menjadi masalah penting dalam hal ini. Namun, Sato tidak yakin tentang sejauh mana masalah yang disebabkan oleh sistem ini, karena kurangnya produksi dan keberadaan pasar gelap.

Meskipun persiapan, koordinasi dan komunikasi yang lebih baik memungkinkan pihak berwenang untuk menghindari fragmentasi dan halangan dalam sistem pembelian dan distribusi beras di Jawa selama masa pendudukan Jepang, sulit untuk melihat bagaimana sistem yang lebih baik dapat mencegah penurunan produksi pangan secara drastis. Bagaimanapun, 
pihak berwenang Jepang juga mencoba untuk merangsang produksi pangan dengan memperkenalkan berbagai teknik budidaya yang unggul secara teknis, dan kegagalan usaha untuk menghentikan penurunan produksi pangan tidak dapat dijelaskan sepenuhnya dengan mengacu pada hambatan fisik selama tahun 1944-5, atau cacat dalam sistem pengadaan.

Masalah utama dalam menjelaskan penurunan produksi pangan adalah kenyataan bahwa pendudukan Jepang mengganggu ekonomi Jawa secara keseluruhan. Pada masa penjajahan kolonial, keseimbangan antara persediaan makanan dan pertumbuhan penduduk di Jawa telah dipelihara di sisi penawaran oleh perubahan teknologi dalam produksi padi yang membantu meningkatkan ketersediaan pangan, dan yang lebih penting, pada sisi permintaan secara bertahap meningkatkan kemampuan untuk membeli produk makanan di kedua wilayah dan kelompok sosio-ekonomi. Selain itu terjadi pula peningkatan jumlah orang yang menemukan peluang pendapatan di sektor lain, misalnya, pertanian perkebunan dan industri manufaktur. Semakin meningkatnya pekerja di luar sektor pertanian tersebut tidak menyebabkan turunnya produksi makanan per kapita, dan kenaikan peluang pendapatan di luar pertanian memungkinkan orang tersebut membeli produk makanan (Van der Eng, 1993: 14). Permintaan yang dihasilkan memberi perangsang bagi petani padi di Jawa Barat dan Jawa Timur, di mana sebagian besar surplus beras Jawa diproduksi untuk meningkatkan produksi surplus.

Selama pendudukan Jepang, perdagangan luar negeri hilang, dan hilangnya peluang perdagangan menyebabkan turunnya pertanian perkebunan dan industri manufaktur yang bergantung pada barang modal impor, suku cadang dan bahan baku. Selain itu, serangkaian tindakan Jepang, seperti pembongkaran beberapa industri dan sebagian jaringan transportasi, mengurangi sejumlah besar pekerja upahan Jawa untuk penghidupan mereka. Oleh karena itu, kemungkinan kunci untuk menafsirkan kelaparan di Jawa selama tahun 1944 dan 1945 dapat ditemukan dalam menurunnya kemampuan untuk membeli makanan di beberapa daerah, terutama di kalangan orangorang yang bergantung terutama pada pendapatan dari tenaga kerja upahan (Sen, 1981: 45-51). ${ }^{5}$

Pasar gelap untuk produk makanan terus ada, meskipun ada pembatasan perdagangan dan transportasi, serta pekerja bergaji yang memiliki aset dapat menukarnya di pasar gelap dengan makanan untuk menambah jatah mereka. Namun, harga beras di pasar gelap beras meningkat tiga kali lipat selama tahun 1942-5, sementara itu peredaran uang di Jawa juga meningkat sebesar lima kali lipat, yaitu dari $f 450$ juta pada bulan Maret 1942 menjadi $f 2.3$ miliar pada bulan Agustus 1945 (Brugmans, 1960: 257; Manschot, 1946: 196-200,

5) Terjadinya kelaparan di Jawa selama tahun 1944 dan 1945 dapat dianalisis dengan menggunakan kerangka kerja kausal yang dikembangkan oleh A.K. Sen, yang berpendapat bahwa kelaparan tidak harus karena ketidaktersediaan makanan yang cukup untuk dimakan, melainkan karena kelompok orang yang tidak bisa membeli makanan yang cukup. 
213-5). yang menunjukkan bahwa kenaikan harga beras di pasar gelap tidak hanya mencerminkan depresiasi mata uang, namun semakin minimnya stok beras. Meningkatnya kesenjangan antara harga beras resmi dan pasar gelap membuat produksi beras menjadi semakin tidak menguntungkan dengan harga beli yang ditentukan. Oleh karena itu, petani memiliki sedikit intensif, selain paksaan, untuk bekerja sama dengan sistem pembelian resmi. Pada saat yang sama, kontrol yang dilakukan oleh pemerintah Jepang dan pangreh praja terhadap perdagangan bebas dan pengangkutan produk makanan cenderung mengurangi pasokan makanan ke pasar gelap dan memperburuk ketidaksesuaian antara harga beras di pasar gelap dan harga beras resmi. Dengan kata lain, pasar gelap tidak dapat memperbaiki kekurangan dalam sistem pembelian dan distribusi resmi. Para petani dihalangi untuk menyuplai beras ke pasar gelap, sementara buruh upahan merasa semakin sulit untuk membeli makanan untuk menambah jatahnya.

Argumen makalah ini dirangkum dalam bentuk grafik pada Figur 2. Bagan ini menunjukkan total pasokan $\left(S^{I}\right)$ dan total permintaan $(D)$ di pasar beras di Jawa dan perubahan ekonomi utama pada persediaan beras selama tahun 1944-5. Anggapannya adalah pasar beras Jawa masih bersatu selama tahun-tahun tersebut. Pembatasan yang diberlakukan pada perdagangan dan transportasi mungkin memberi kesan sebaliknya, namun keberadaan pasar gelap menunjukkan bahwa beras terus diperdagangkan dari daerah surplus ke daerah defisit beras. Situasi ekuilibrium $\left(E^{1}\right)$ akan muncul jika situasinya tidak berubah dibandingkan tahun-tahun sebelumnya dapat diperkirakan dengan situasi selama tahun 1942 dan 1943. Dengan demikian, kuantitas ekuilibrium $\left(q_{e}\right)$ menjadi sekitar 2,3 juta ton beras, atau sekitar setengah dari

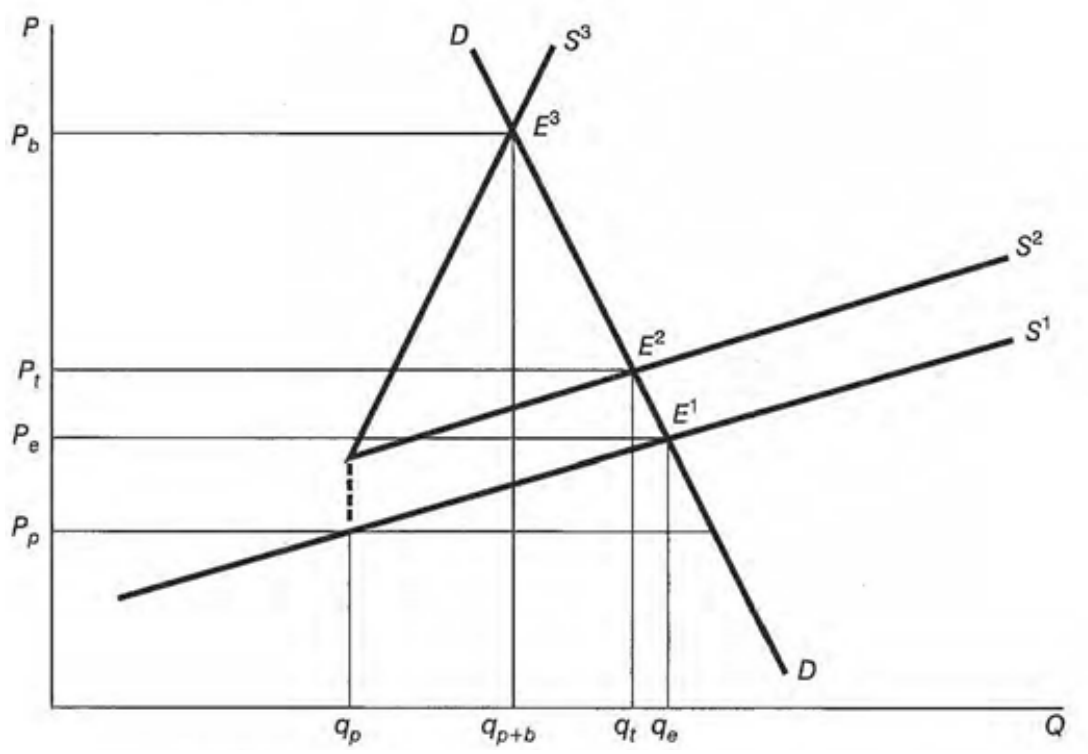

Figur 2. Kesan skematis dari perubahan utama dalam penawaran dan permintaan di pasar beras di Jawa selama tahun 1943-6. 
total produksi. Ini adalah jumlah total yang dihasilkan, dikurangi penggunaan subsisten oleh rumah tangga petani.

Efek pertama yang harus dipertimbangkan adalah pembelian beras oleh pihak Jepang. Seperti ditunjukkan Tabel 5, harga beli $\left(p_{p}\right)$ padi (dalam hal ini adalah beras) jauh di bawah harga kliring di pasar gelap $\left(p_{b}\right)$. Karena dalam kenyaraannya pemerintah Jepang menawarkan harga beli yang rendah, maka jumlah beras yang berhasil mereka beli $\left(q_{p}\right)$ jauh di bawah 2,3 juta ton: 1,4 juta ton pada tahun 1944 dan 1,7 juta ton pada tahun 1945.

Perbedaan $\left(q_{e}-q_{p}\right)$ bisa saja dijual di pasar gelap. Namun, mengingat banyaknya kekurangan makanan secara drastis, jumlah beras yang diperdagangkan di pasar gelap diperkirakan jauh lebih kecil dari $\left(q_{e}-q_{p}\right)$. Ada dua penjelasan utama untuk kondisi ini. Salah satunya adalah dampak dari berbagai hambatan fisik terhadap produksi dan pasokan. Faktor-faktor ini secara efektif meningkatkan biaya satuan untuk memasok stok beras. Salah satu unsur penting mungkin adalah biaya transportasi beras yang lebih besar. Jika pengangkutan beras dibatasi oleh kekurangan gerbong kereta dan truk pengangkut, pada prinsipnya akan diganti dengan sarana transportasi lain, seperti gerobak sapi atau bahkan sepeda. Dalam prakteknya sarana transportasi seperti itu tidak dapat menangani volume barang yang sebelumnya diangkut dengan kereta api dan jalan darat, bukan karena sarana transportasi alternatif semacam itu sulit diatur, namun karena angkutan tersebut jauh lebih mahal dan akan meningkatkan biaya pemasokan beras.

Hambatan fisik terhadap produksi dan pemasaran beras, seperti kesulitan transportasi, akan meningkatkan biaya satuan daripada biaya marjinal untuk memasok beras. Efek ini ditunjukkan pada grafik dengan pergeseran kurva penawaran dari $S^{1}$ ke $S^{2}$. $S^{2}$ terpotong di sisi kiri karena pasokan beras pada jumlah sampai $q_{p}$ ditentukan oleh kebijakan pembelian dan transportasi dari Kantor Pasokan Pangan, yang menetapkan biaya transportasi di bawah pasar. Pasokan beras di segmen pasar ditentukan oleh $S^{1}$. Sebagai konsekuensinya, misalnya, biaya transportasi yang lebih tinggi, pasar mencapai ekuilibrium baru $\left(E^{2}\right)$, di mana harga $\left(p_{t}\right)$ melebihi harga beli $\left(p_{p}\right)$, dan jumlah kuantitas yang diminta dan dipasok turun dari $q_{e}$ ke $q_{i}$.

Alasan kedua mengapa jumlah beras yang diperdagangkan di pasar gelap jauh lebih kecil daripada yang mungkin terjadi dalam keadaan normal adalah larangan perdagangan dan transportasi beras tanpa izin dari Kantor Pasokan Pangan. Secara umum, pasokan produk di pasar pangan sangat elastis, yang berarti bahwa perubahan kecil pada harga pasar memicu perubahan substansial dalam kuantitas yang ditawarkan. Pasar beras Jawa tidak bisa dikecualikan dengan peraturan ini, mengingat ada beberapa juta petani padi. Namun, operasi pasar gelap dan tindakan yang semakin ketat yang dilakukan untuk mengendalikannya secara drastis meningkatkan biaya marjinal untuk memasok beras. Risiko untuk terlibat dalam perdagangan beras di pasar gelap 
pun cukup besar. Risiko bagi produsen dan pedagang tidak hanya melibatkan kemungkinan hilangnya stok beras, tapi juga denda yang berat. Memang, hal tersebut relatif mendorong terjadinya pasar bebas, di mana pemasok di pasar gelap pada umumnya menghadapi biaya marjinal yang jauh lebih tinggi dan cepat untuk memasok produk mereka. Efek ini ditunjukkan pada grafik dengan pergeseran kurva penawaran dari $S^{2}$ ke $S^{3}$. Sebagai konsekuensinya, pasar mencapai ekuilibrium $\left(E^{3}\right)$, di mana harga pasar gelap $\left(p_{b}\right)$ jauh melebihi harga beli (pp), dan jumlah kuantitas yang diminta dan dipasok turun menjadi $q_{p+b}$ kuantitas yang dibeli oleh agen logistik makanan ditambah jumlah yang diperdagangkan di pasar gelap.

Argumen utama dalam makalah ini adalah bahwa efek kedua sangat melebihi efek pertama. Tabel 5 menunjukkan kenaikan tiga kali lipat harga beras di pasar gelap dari tahun 1942-5. Jika kenaikan lima kali lipat volume uang yang disebutkan di atas mendekati depresiasi mata uang umum, maka harga riil beras di pasar gelap meningkat enam kali lipat. Tidak ada bukti langsung mengenai perbedaan biaya transportasi antara truk dan gerobak sapi, namun perbandingan bukti dari berbagai negara berkembang menunjukkan bahwa biaya pengangkutan beras oleh gerobak sekitar 15 kali lipat dari transportasi dengan truk (Clark dan Haswell, 1970: 191-200). Dengan mengasumsikan marjin transportasi awal dalam harga beras menjadi 5 persen, orang akan menyimpulkan bahwa biaya transportasi yang lebih tinggi menaikkan biaya per unit untuk memasok beras sebesar 15 x $5=75$ persen, yang tidak cukup untuk menjelaskan kenaikan enam kali lipat harga beras sesungguhnya di pasar gelap. Makalah ini menyatakan bahwa kenaikan tersebut sebagian besar dapat dijelaskan sebagai konsekuensi dari penciptaan pasar gelap, seperti yang telah diuraikan di atas. Petani dihalangi untuk menghasilkan surplus untuk pasar gelap, sementara buruh upahan merasa semakin sulit untuk membeli makanan untuk menambah jatah mereka.

Sebagai kesimpulan, masalah persediaan makanan di Jawa selama pendudukan Jepang bukan terletak pada sistem pembelian yang dilakukan Jepang, atau dampak korupsi, namun kenyataan bahwa pihak berwenang berusaha mengendalikan seluruh pasar beras, baik dari sisi pasokannya maupun sisi permintaan. Dengan demikian, mereka mengambil insentif dari petani yang bisa menghasilkan surplus yang signifikan. Petani kemudian merasa lebih mudah untuk mengurangi produksi mereka saat harga beli resmi disusutkan. Mereka memilih memproduksi beras dalam jumlah yang cukup banyak untuk memenuhi kebutuhan mereka sendiri, sedangkan untuk mencukupi kuota resmi dilakukan hanya jika diperlukan. Di atas itu mereka mungkin telah menghasilkan surplus untuk pasar gelap, namun surplus ini jauh lebih kecil daripada surplus yang dapat dipasarkan sebelum pendudukan Jepang.

Upaya untuk mengendalikan pasar adalah perbedaan utama antara 
sistem intervensi Jepang di pasar beras dan operasi Yayasan Bahan Makanan zaman kolonial, serta lembaga logistik makanan yang didirikan di Indonesia setelah kemerdekaan dan setelah tahun 1949, yang tidak berupaya untuk mengendalikan dan mengatur seluruh pasar beras (Sadli, 1961: 33-44; Moeljono, 1971: 56-79). ${ }^{6}$ Hal tersebut menjelaskan bahwa bukan karena ketidakmampuan kebijakan yang dilakukan oleh Jepang dalam membeli dan mendistribusikan beras sebagai masalah utamanya, namun klaim yang relatif cukup mengenai produksi pangan di Jawa memiliki dampak buruk pada makanan pasokan di Jawa selama pendudukan Jepang.

\section{Catatan Tambahan}

Sejak publikasi artikel ini pada tahun 1998, beberapa publikasi telah membahas aspek-aspek penurunan produksi pangan 1940-6 dan kelaparan tahun 1944-5 di Jawa. Van der Eng (2010) menganalisis tingginya tingkat integrasi pasar beras di Jawa selama tahun 1930-an dan kemampuan pasar untuk mengurangi kekurangan produksi regional. Kebijakan pembelian padi oleh pemerintah Jepang di Jawa selama 1942-5 hampir sepenuhnya melumpuhkan proses ini, dengan konsekuensi yang sangat buruk. Brennan dll. (2017) menekankan parahnya bencana kekeringan pada 1944 dan dampaknya terhadap produksi pertanian dengan memperpanjang musim kemarau 1944, menunda musim tanam 1944-5, dan menunda panen utama tahun 1945.

Van der Eng (2002) menganalisis bukti demografis yang tersedia untuk Indonesia selama tahun 1940-an. Dia menemukan bahwa kekurangan pangan yang meningkat memaksa banyak orang pedesaan untuk mencari perlindungan di daerah perkotaan dengan harapan menemukan persediaan makanan. Namun, sistem distribusi beras Jepang hanya disediakan untuk populasi perkotaan yang telah terdaftar. Sebagian besar migran baru ke daerah perkotaan dikeluarkan dari sistem ini dan menderita kelaparan, terutama selama 1944-5 ketika pertumbuhan populasi di sebagian besar Jawa menunjukan angka negatif. Huff (2019) membandingkan kelaparan di Jawa dan di Tonkin (Vietnam Utara) selama 1944-5. Dia membenarkan bahwa kemungkinan besar 2,4 juta orang di Jawa tewas selama masa kelaparan. Sebaliknya, dalam Encyclopedia of Indonesia in the Pacific War [Ensiklopedia Indonesia dalam Perang Pasifik], Sato (2010: 257-258) berpendapat bahwa tidak ada laporan oleh otoritas Jepang tentang kelaparan hebat di Jawa dan terus terang menyatakan 'Indonesia tidak mengalami kelaparan bencana

6) Hingga tahun 1975, lembaga logistik makanan menggunakan target, namun perbedaan antara target dan pembelian aktual dapat dipenuhi dengan beras impor. Hal ini menjadi sulit di awal tahun 1960an karena kekurangan devisa Indonesia. Pada saat itu operasi lembaga logistik pangan memang mulai menyerupai pendahulunya selama pendudukan Jepang. Ini juga mulai bekerja dengan kuota pembelian dan dengan cepat terdepresiasi harga beli. Namun, pada saat itu, target pembelian beras hanya 8 persen dari produksi padi di Jawa. 
seperti yang ada di Vietnam utara atau timur laut India' (h.267). Seperti yang dia lakukan dalam bukunya Mobilisasi dan Kontrol (1993), Kurasawa (2015) berpendapat bahwa kekurangan pangan selama pendudukan Jepang terkait dengan rendahnya produktivitas petani padi di Jawa dan penolakan mereka untuk menggunakan metode produksi beras Jepang yang dapat meningkatkan produktivitas.

\section{Referensi}

Arsip

ANRI (Arsip Nasional Republik Indonesia)

Djogya Papers, inv.nr.: 5240.

BPRO (British Public Record Office)

F0371/53889 (F9802): 'Photographic Survey of the Rice Producing Areas of Java and Madura; F0371/53907 (F12706): Perjalanan oleh A. Clark Kerr pada bulan Januari 1946 dan Lord Killearn pada bulan Agustus 1846.

\section{Buku dan Terbitan}

Brennan, Lance, Heathcote Les, Lucas, Anton. 'War and famine around the Indian Ocean during the Second World War', Ethics in the Global South - Research in Ethical Issues in Organizations, 18: 5-70, 2017.

Brugmans I.J. et al. (eds). Nederlandsch-lndië onder Japanse Bezetting. Gegevens en Documenten over de Jaren 1942-1945. Franeker: Wever, 1960.

Clark, C. and M. Haswell. The Economics of Subsistence Agriculture. London: Macmillan, 1970.

'De Inlandsche Landbouw in 1939', Economisch Weekblad voor Nederlandsch-Indië, 9, 1940.

'De Rijstpositie van Nederlandsch-Indië', Economisch Weekblad voor NederlandschIndië, 12, 1946.

de Vries, E. 'Het Javaansche Rijstjaar', Economisch Weekblad voor Nederlandsch-Indië, 1,1933

Ecimovic, J. 'Report to the Government of Indonesia on Agricultural Statistics'. Roma: Food and Agriculture Organization, 1957.

'Fotografische Opname van de Rijstproduceerende Gebieden op Java en Madoera', Economisch Weekblad voor Nederlandsch-Indië, 12, 1946.

Fukami S. 'Nihon Gunseika Jawa ni okeru Chosa Kenkyu Kikan', Nichiran Gakkaishi, 13, 1988.

Fukami S. 'Japanese Source Materials on the Japanese Military Administration in Indonesia', Utrechtse Historische Cahiers, 7, 2/3, 1989.

Geoogste Uitgestrektheden en Productie van de Voornaamste Voedingsgewassen op Java en Madoera 1937-1946. Jakarta: Centraal Kantoor voor de Statistiek, 1947.

Hadiwinoto, S. 'Masalah Beras', Warta Ekonomi di Indonesia, 12, 1959.

'Het Centraal Kantoor voor de Statistiek', Economisch Weekblad voor NederlandschIndië, 12, 1946.

Hollinger, W.C. dan A.D. Tan, 'The National Income of Indonesia, 1951-1952', Ekonomi dan Keuangan Indonesia, 10.

Huff, Gregg. 'The Great Second World War Vietnam and Java Famines', Modern 
Asian Studies (cetak), 2019. https://doi.org/10.1017/S0026749X18000148.

Kort Overzicht van de Ontwikkeling van de Economische Situatie in de Republiek Indonesia sinds Haar Oprichting', 1947.

Kurasawa A. 'Mobilization and Control. A Study of Social Change in Rural Java, 1942-1945'. Disertasi Ph.D., Cornell University, 1988.

Kurasawa A. Kuasa Jepang di Jawa: Perubahan Sosial di Pedesaan 1942-1945. Depok: Komunitas Bambu, 2015.

'Landbouwvoorlichting in Oost-Java tijdens de Japansche Bezetting', Landbouw, 19, 1946.

Luas Panen dan Produksi Tanam2an Rakjat Berumur Pendek di Djawa dan Madura (1963-4).

Maandciffers over den Economische Toestand der Inheemsche Bevolking op Java en Madoera (1935-1940).

Manschot, H.J. 'Het Geld-, Bank- en Credietwezen in Nederlandsch-Indië in de Bezettingsjaren 1942/1945', Economisch-Statistische Berichten, 31, 1946.

Mededeelingen der Regeering omtrent Enkele Onderwerpen van Algemeen Belang. Jakarta: Landsdrukkerij, 1928.

Moeljono S. Seperempat Abad Bergulat dengan Butir-Butir Beras. Jakarta: Badan Urusan Logistik, 1971.

Sadli , M. 'Kesimpulan2 Mengenai Sistim Pembelian Padi untuk Pemerintah jang Ditjepat', Warta Research, 2, 1961.

Sato, S. War, Nationalism and Peasants: Java under the Japanese Occupation. Sydney: Allen and Unwin, 1994.

Sato, Shigeru. 'Relocation of labor and the romusha issue' dan 'Economic life in villages and towns' di Post, Peter (ed.) The Encyclopedia of Indonesia in the Pacific War, 245-261 and 267-279. Leiden: Brill, 2010.

Scheltema, A.M.P.A. 'Rice Production on Java en Madoera', Proceedings of the Fourth Pacific Science Congress Java 1929, Vol. 4. Agricultural Papers. Bandung: Maks \& Van der Klis, 1930.

Scheltema, A.M.P.A. 'De Statistiek van den Inlandschen Landbouw op Java en Madoera' dalam Landbouw, 6, 1930/31.

Sen, Amartya. Poverty and Famines: An Essay on Entitlement and Deprivation. Oxford: Clarendon Press, 1981.

Soebardjo, A. 'The Life Conditions of the Population with Regard to the Requisition of Paddy by the Government', Wason Collection, Cornell University Library, No. 905/3/16, 1944.

Postmus, S. dan A.G. van Veen. 'Dietary Surveys in Java and East Indonesia' dalam Chronica Naturae, 105, 1949.

Van de Graaff, E.A. De Statistiek in Indonesië. The Hague: Van Hoeve, 1955.

Van der Eng, Pierre. Food Consumption and Standard of Living in Indonesia, 1880-1990. Canberra: Research School of Pacific Studies, Economics Division Working Paper, Southeast Asia No. 93/1, Australian National University, 1993.

Van der Eng, Pierre. Food Supply in Java during War and Decolonisation, 1940-1950. Hull: Centre for South-East Asian Studies Occasional Paper No. 25, University of Hull, 1994.

Van der Eng, Pierre. Agricultural Growth in Indonesia: Productivity Change and Policy Impact since 1880. London: Macmillan, 1996.

Van der Eng, Pierre. 'Bridging a gap: A reconstruction of population patterns in 
Indonesia, 1930-1961', Asian Studies Review, 26(3) 487-509, 2002.

Van der Eng, Pierre. 'Market responses to climate stress: Rice in Java in the 1930s'

[Respons pasar terhadap stres iklim: Beras di Jawa pada 1930-an], Australian

Economic History Review, 50(1) 62-79, 2010.

Van Veen, A.G. 'Nutrition Studies in Indonesia 1850-1950' dalam Documenta Neerlandica et Indonesica de Morbis Tropicis, 1, 1950.

'Voedingsproblemen en Overheidspolitiek op Java en Madoera', Koloniaal Tijdschrift 29, 1940. 